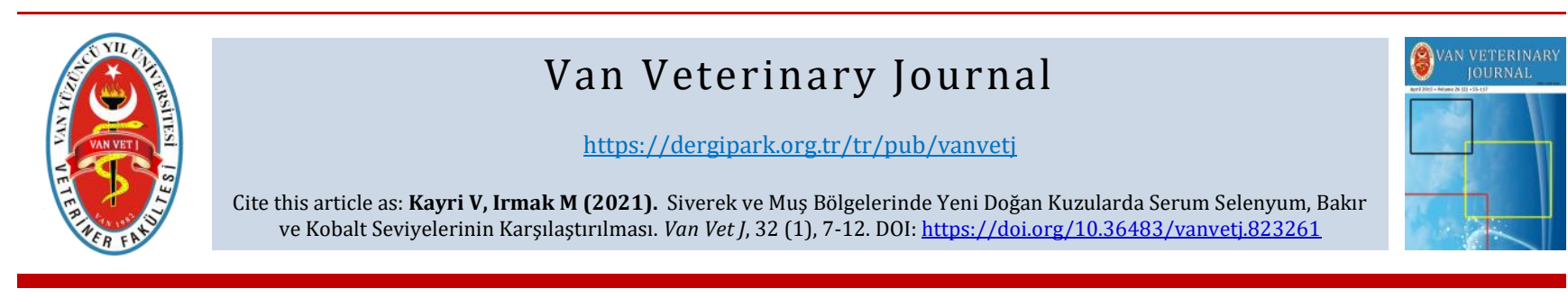

\title{
Comparison of Serum Selenium, Copper and Cobalt Levels in Newborn Lambs in Siverek and Muş Regions
}

\author{
Veysi KAYRI*i] Mehmet IRMAK@i)
}

Muş Alparslan University, Faculty of Applied Sciences, Animal Production and Technologies Department, 49210, Muş, Türkiye

Received: 11.09 .2020

Accepted: 16.02 .2021

\begin{abstract}
In this study, serum selenium (Se), copper ( $\mathrm{Cu}$ ) and cobalt (Co) values were investigated in 20-30 day-old lambs born from healthy akkaraman sheep raised in pasture conditions in Siverek and Mus regions, not given supplementary feed and showing no clinical symptoms. 18 lambs, 9 females and 9 males, and 36 lambs in total were used for research. Mineral matter analyzes were determined by Atomic Absorption Spectrometer. While there was no difference between the regions in terms of serum copper levels $(\mathrm{P}>0.05)$; significant differences were found between serum Se and Co values $(\mathrm{P}<0.05)$. While average serum selenium level was found to be high in both regions, serum $\mathrm{Cu}$ level was found to be lower than the reference values. Serum Co value was found between normal values in both Siverek and Muş. As a result, it was concluded that the lambs should be given Cu support during pasture-based breeding in Siverek and Muş.
\end{abstract}

Keywords: Cobalt, Copper, Selenium

öz

\section{Siverek ve Muş Bölgelerinde Yeni Doğan Kuzularda Serum Selenyum, Bakır ve Kobalt Seviyelerinin Karşılaştırılması}

Bu çalışmada Siverek ve Muş bölgelerinde mera koşullarında yetiștirilen, takviye yem verilmeyen ve klinik belirti göstermeyen sağlıklı akkaraman ırkı koyunlardan doğan 20-30 günlük kuzulardaki serum selenyum (Se), bakır (Cu) ve kobalt (Co) değerleri araştırıldı. Araştırılmak üzere her bölgeden 9 dişi 9 erkek olmak üzere 18, toplamda ise 36 kuzu kullanıldı. Mineral madde analizleri Atomik Absorbsiyon Spektrometrede tayin edildi. Bölgeler arasında serum $\mathrm{Cu}$ düzeyleri bakımından farklılık bulunmazken $(\mathrm{P}>0.05)$; serum Se ve Co değerleri arasında önemli farklılıklar tespit edildi $(\mathrm{P}<0.05)$. Her iki bölgede de ortalama serum Se düzeyi yüksek bulunurken, serum Cu düzeyi referans değerlerden düşük olarak bulundu. Serum Co değeri ise hem Siverek hem de Muş'ta normal değerler arasında tespit edildi. Sonuç olarak, Siverek ve Muș'ta meraya dayalı yetiștiriciliğin yapıldığı dönemde kuzulara $\mathrm{Cu}$ desteği verilmesi gerektiği kanaatine varıldı.

Anahtar Kelimeler: Bakır, Kobalt, Selenyum

\section{GíRiş}

Mineraller, canlı organizmada düşük konsantrasyonlarda bulunmalarına rağmen, enzimal aktivite, hücrede ozmotik basıncın regülasyonu, hormonal aktivite, kollagen oluşumu, oksijenin taşınması, fertilite, canlı ağırlık kazancı ve hastalıkların önlenmesi gibi birçok fizyolojik aktivitenin devamlılığı için önemli roller taşımaktadırlar. Mineral maddelerin eksikliğinde beslenmeye bağlı hastalıklar ortaya çlkmakta ve yetiştirici açısından büyük ekonomik kayıplar gerçekleșmektedir (Underwood ve Sutt 1999).

Keşfedildikten uzun bir süre sonrasına kadar karsinojenik bir mineral olarak tanımlanan Se, ilk kez 1957 yllında canlı organizma için faydalı olduğu saptanmıștır. Se, antioksidan (Rayman 2000), antienflamatuar (Aaseth ve ark. 2016), antimutajenik (Peng ve ark. 2016), antikarsinojenik (Ahmad ve ark. 2015), kemopreventif (Combs ve ark. 1998) ve antibakteriyel (Cihalova ve ark. 2015) özellikleri olan bir iz elementtir. Se bütün bu özelliklerinin yanı sıra fizyolojik açıdan önemli bir dizi sürece katılan selenoproteinlerin ayrılmaz bir bileșenidir (Pascual ve Aranda 2013). Esansiyel bir mineral olan Se, bitkiler tarafından topraktan emilirler. İnsan ve hayvanların bitkileri tüketmesi ile Se ihtiyacı karşılanmaktadır (Bağdaș ve Ylldız 2004). Topraktaki Se seviyesi 0.2 ppm dolaylarındadır. Se yönünden fakir meralarda otlayan koyunlardan doğan kuzularda beyaz kas hastalığı insidansı yükselmektedir (Kurt ve ark. 2001). Se içeriği düşük olan topraklarda yetişen bitkilerin tüketilmesi hayvanların Se ihtiyacını karşılamaya yetmemektedir. Ayrıca toprak pH sının asidik olması ve toprakta fazla miktarda sülfat olması Se'nin bitkiye geçișini kısıtlamaktadır (Dabak ve ark. 2002). Se rumen mikroorganizmaları tarafindan organizmanın kullanamayacağı formlara indirgendiğinden dolayı ruminantlarda monogastrik hayvanlara göre emilimi daha düșük olmaktadır. Se ve E vitamini 
eksikliğinin aynı anda görülmesi sonucunda beyaz kas hastalı̆̆ (white muscle disease), infertilite, abort, metritis, östrüs gecikmesi veya anöstrüs, immun sistemin zayıflaması gibi semptomlar gözlenmektedir (Bozena ve ark. 2017). Tiroid hormonu canlılarda büyüme, gelişme, enerji metabolizması, verim miktarı gibi birçok mekanizmada rol oynamaktadır. Se eksikliğinde, tiroid hormonlarından T4 ve TSH hormonu yükselirken, T3 hormonunun düștüğü yapılan çalıșmalar ile ortaya konmuştur (Gustavo ve ark. 2018).

Beyaz kas hastalığı, dünyanın birçok bölgesinde görülen Se ve E vitaminin eksikliğinde ortaya çıkan beslenmeye bağlı bir hastalıktır (Gustavo ve ark. 2018). Ülkemizde özellikle Doğu Anadolu ve Güneydoğu Anadolu bölgelerinde görülen beyaz kas hastalığı, kalp kası ve iskelet kaslarında dejenerasyonlara yol açarak kuzularda ölümlere neden olan bir hastalıktır. Kuzularda başlarda harekette güçlük, ayakta duramama, kısa ve dik adımlar, beli kambur tutma semptomları ile görülen beyaz kas hastalığı ilerleyen süreçlerde paralize yol açmaktadır. Beyaz kas hastalığına yakalanan kuzuların daha çok pnömoni, kalp yetmezliği ve açlıktan öldüğü rapor edilmiştir (Bildik ve ark. 2007). Fazla miktarda alınan Se solunum, terleme, idrar ve defekasyonla vücuttan uzaklaştırılmaktadır (Eren 2009).

$\mathrm{Cu}$, askorbit asit, oksidaz, tirosinaz, laktoz ve monoamin oksidaz gibi yükseltgeyici enzimlerin bir bileşeni olarak bitki ve hayvan organizmasında eser miktarda bulunmaktadır. $\mathrm{Cu}$, Canlı organizmadaki fizyolojik ve biyokimyasal aktivitelerin devamlılığı için gereklidir (Malkin ve Malmstrom 1970). Bilinen en eski elementlerden olan $\mathrm{Cu}, 1928$ yılında dıșarıdan alınması zorunlu olan iz element olarak kabul edilmiștir. $\mathrm{Cu}$, yağ metabolizmasında, kemik dokusu oluşumunda, kalp kasında, bă̆ doku gelişiminde, omurilikte miyelin yapımında, fertilizasyonda, yapağı oluşumunda ve sinir sisteminin gelişiminde, doku pigmentasyonunda, bağışıklık sisteminde ve dokulardaki oksidasyon olaylarında önemli görevler üstlenmenin yanı sıra kan yapımı boyunca demir'le $(\mathrm{Fe})$ beraber aktivite göstermektedir (Shehata ve ark. 2019). Ayrica Cu. Fe'nin absorbsiyonunda, dokulardan taşınmasında ve hemoglobin yapımına katılmasında görev almaktadır (Al Busadah 2003; Jung-Heun ve James 2018). Serumdan ayrılan $\mathrm{Cu}$, diğer birçok dokuda olduğu gibi, kıl ve yün oluşumunda da etki göstermektedir. Bu nedenle yün ve kllların mineral düzeylerinin belirlenmesiyle hayvanın mineral seviyesi hakkında fikir yürütülebilir (Erika ve ark. 2020). Emilimi ince bağırsaklarda gerçekleşen Cu'nun yaklaşık \%5'i dolaşım sistemine katılmaktadır. Kandaki Cu'nun yaklaşık \%60'ı serumda, \%40'ı eritrositlerde ve çok az bir kısmı lökositlerde bulunmaktadır (Çimtay ve ark. 2000). Canlı organizmadaki Cu düzeyi mevsim, ırk, yaș, coğrafik farklılıklar, gebelik ve süt verimi gibi farklı parametrelere göre farklılık gösterebilmektedir (Yalçınkaya ve ark. 2010; Ming ve ark. 2018).

Rasyonla yeterli miktarda $\mathrm{Cu}$ alınamaması veya rasyondaki $\mathrm{Cu}$ absorbsiyonunun çeşitli nedenlerle kısıtlı olmasıyla șekillenen $\mathrm{Cu}$ yetersizliği, subklinik veya klinik olarak ortaya çlkmakta ve daha çok ekstansif yetiştiricilik yapılan sürülerde görülmektedir. Rasyonla yeterli düzeyde $\mathrm{Cu}$ alan sürülerde klinik semptomların daha hafif seyrettiği yapılan çalışmalarda rapor edilmiştir (Gretchen ve Marcia 2019). Genç hayvanlar $\mathrm{Cu}$ eksikliğine daha duyarlıdır. $\mathrm{Cu}$ eksikliğinde ortaya çıkan gelişim bozukluğu ve canlı ağırlık kaybının oksidasyondaki aksaklıklar sonucu metabolik aktivitelerdeki bozukluklardan kaynaklandığı düşünülmektedir. (Purchase 2013). Cu antioksidan enzim üretimine katılması sebebi ile immun sistem için çok önemlidir. Cu'nun katıldığı en önemli enzim sistemleri oksidazlardır. $\mathrm{Cu}$; lisiloksidaz, süperoksitdismutaz, süperoksidaz, tirozinaz, seruloplazmin ve sitokromoksidaz gibi enzimlerin bir bileșenidir. Bu enzimlerin, kollajen ve elastinin yapısal bütünlügü̈, süperoksit radikallerin detoksifikasyonu, pigmentasyon, demirin taşınması ve enerji metabolizması açısından önemli olduğu rapor edilmiştir (Gazioğlu ve Balıkcı 2017). Cu eksikliği ile kuzularda enzootik ataksi, kansızlık, bağışıklık sisteminin zayıflaması, gelişimde yavaşlama, kilo kaybı, ishal, kaba ve karmaşık yapağı yapısı ve kıllarda depigmentasyon gibi semptomlar görülmektedir. Cu yetersizliğinde tipik bulgu, karpal bölgede beliren şişkinliklerdir (Ting ve ark. 2020). Etiyolojisinde gebelik sürecinde vücutta yetersiz $\mathrm{Cu}$ bulunması olan enzootik ataksi, kongenital bir hastalıktır ve daha çok 2-4 aylık kuzular bu hastalıktan etkilenmektedir. Rakımı yüksek meralarda, mera ıslah çalışmalarının çok sık yapıldığı bölgelerde ve toprağında kireç bulunan meralarda otlayan hayvanlarda hastalık insidansı artmaktadır (Ayhan ve ark. 2012). Cu miktarının çok düşük olduğu durumlarda kuzular hasta olarak doğmalarına rağmen klinik bulgulara daha çok 1-2 aylık olduktan sonra rastlanmaktadır. Ataksi durumlarında kuzuların arka bacaklarında inkoordinasyon, parezis, köpek oturuşu, toprak yeme ve göğüs üzerine yatma gibi klinik bulgular görülmekte ve tedavi edilmediği takdirde 34 hafta içinde ölüm şekillenmektedir (Can J 1974). Ülkemizin hemen hemen her bölgesinde $\mathrm{Cu}$ eksikliği sonucu kuzularda ortaya çıkan enzootik ataksi hastalığının teşhisinde kan $\mathrm{Cu}$ düzeyinin 0.5 ppm'den az olması kriter olarak bildirilmiştir (Tiftik ve Doğanay 1997).

Geviş getiren canlılar için dışarıdan alınması zorunlu elementlerden biri olan Co, rumen mikroorganizmaları tarafından kullanılarak kobalamin (Vit B12) sentezinde rol almaktadır (Bilal ve Bilal 2005). Kobalamin'in nukleusunu Co olușturduğundan sentezlenmesi için gereklidir. B12 vitaminin yaklaşık \%4'ünü Co oluşturmaktadır (Batmaz 2013). B12 vitamini ruminantlarda monogastrik hayvanların aksine, rumende mikroorganizmalar tarafından oluşturulmaktadır. Kobalamin sentezi için rasyonla birlikte yeterli düzeyde Co alınmalıdır (Aksoy 2016).

Co eksikliği olan kuzularda gelişimde yavaşlama, pika, zayıflık, anemi ve ikterus gibi semptomlar görülmektedir (Aksoy 2016; Şimşek 2016). Co yetersizliğinde beyaz karaciğer hastalığı oluşmakta ve semptomlar kuzularda daha şiddetli seyretmektedir (Batmaz 2013). Beyaz karaciğer hastalığı, koyunlarda verim miktarında büyük düşüşlere sebep olan ve Co eksikliği ile ortaya çlkan, karaciğerde yağ birikimi ile ilişkili bir karaciğer hastalığıdır (Radostits 2008; Pugh ve Baird 2012; Erkılıç ve Erdoğan 2016). Hastalık ekstansif yetiștiriciliği yapılan koyun ve keçilerde görülürken entansif yetiștiricilikte görülmemektedir. Ruminantların diyetlerinin yeterli düzeyde Co ihtiva etmesi gerekmektedir (Aksoy 2016). Diyette Co miktarının $0.8 \mathrm{mg} / \mathrm{kuru}$ madde (KM)'den az olması yetersiz olarak kabul edilmektedir (Bilal ve Bilal 2005). Rasyonda Co miktarının düşük olmasının temel nedeninin toprakta Co elementinin az bulunmasından kaynaklandığı kabul edilmektedir. Volkanik, drenajı kötü olan, erozyonlu ve kıraç yerlerde yetişen bitkiler Co bakımından fakirdir. Yapılan çalıșmalarda koyun ve keçilerin sığırlara oranla hastalığa daha kolay yakalandığı ve genç hayvanların erişkinlere göre hastalığa daha duyarlı olduğu rapor edilmiștir (Bilal ve Bilal 2005). Kuzuların günlük Co ihtiyacı koyunlara göre daha yüksek olduğundan en az $0.1 \mathrm{mg} / \mathrm{kg} /$ gün alınması gerekmektedir (Radostits 2008; Aitken 2009). Beyaz karaciğer hastalığı, 
0.04-0.07 mg/kg düzeyinden daha az Co içeren rasyonlarla beslenen hayvanlarda görüldüğü saptanmıștır (Aytuğ ve ark. 1990). Rasyonla beraber yeterli Co alamayan hayvanların birkaç ay içerisinde karaciğerlerindeki kobalamin depoları tükenir ve hastalık belirtileri daha da şiddetlenir (Kennedy ve ark. 1997). MacPherson ve arkadaşlarının yaptıkları bir çalışmada, klinik semptom göstermeyen koyunlarda plazma kobalamin düzeyi 400 $900 \mathrm{pg} / \mathrm{ml}$ arasında saptamışlardır. Aynı çalışmada, üç ayrı deneme grubuna ayırdıkları hayvanlarda Co eksikliğinde kan hemoglobin miktarı 6.4- $11.2 \mathrm{~g} / \mathrm{dl}$ olarak belirlenmiștir (MacPherson ve ark. 1977). Kobalamin eksikliğinde anemi, anoreksia, kilo kaybı, verim miktarında azalma, lakrimasyon, ışığa duyarlılık ve bağışıklık sisteminin zayıflaması gibi semptomlar görülmektedir (Vellema ve ark. 1997). Co eksikliğinin klinik semptomları daha çok sütten kesilmiş ve merada otlayan kuzularda ortaya çlkmaktadır (Yeşildere ve Deprem 2009). Kuzularda gelișme geriliği (kaslar zayıf, gögüs kafesi dar ve kafa yapısı büyük), anoreksia, pika, pubertasta gecikme, koyunlarda infertilite, düşük doğum oranı, düşük veya ölü doğum, gastrointestinal sistem bozuklukları, anemi, immun sistemin zayıflaması, süt ve yün veriminde azalma gibi klinik bulgulara rastlanmaktadır (Yeșildere ve Deprem 2009; Duncan ve Morrison 1981).

$\mathrm{Bu}$ çalışma, Siverek ve Muş bölgelerinde yetiștirilen kuzulardaki serum Se, $\mathrm{Cu}$ ve Co seviyelerinin araştırılması ve bu minerallerin eksikliğinde görülen hastalıkların önlenmesi için koruyucu tedbirlerin alınması amacıyla yapılmıştır.

\section{MATERYAL ve METOT}

Siverek ve Muş bölgelerinden 20-30 günlük akkaraman ırkı kuzulardan kan örnekleri alındı. Kan numuneleri vena jugularis'ten jelli kan alma tüplerine alındıktan sonra, 3000 rpm'de $5 \mathrm{dk}$ santifüj edilerek elde edilen serumlar, $30^{\circ} \mathrm{C}$ 'de analiz edilinceye kadar saklandı. Örnekler farklı işletmelerdeki 36 adet kuzudan elde edildi ve cinsiyete bağlı farklılıkları ortadan kaldırmak amacıyla diși ve erkek sayıları eşit tutuldu. Örnek seçiminde kuzulara ve gebeliğin son 1 aylık sürecinden numuneler alınıncaya kadar olan süreçte koyunlara herhangi bir mineral madde takviyesi yapılmadı. Numuneler merada otlayan koyunlardan doğan kuzulardan olușturuldu. Serum Se, $\mathrm{Cu}$ ve Co düzeylerinin araștırılması amacıyla her bir bölgeden 9 dişi ve 9 erkek olmak üzere 18, toplamda ise $36 \mathrm{kuzu}$ kullanılarak serum numuneleri elde edildi. Muș İl Tarım ve Orman müdürlügünün 12.02.2021 tarih ve E.463074 sayılı yazısı ile çalışmanın etik kurul onay belgesine gerek olmadığı belirtilmiştir.

\section{Atomik Absorbsiyon Spektrometrisi}

Serumda mineral madde analizi için triton X-100 çözeltisi kullanılarak seyreltme işlemi yapıldı. Elde edilen serumlardaki $\mathrm{Se}, \mathrm{Cu}$ ve Co elementlerinin analizleri atomik absorpsiyon spektrometresinde (AAS, Thermo Scientific, Model: İCE-3000 series) yapıldı (Morton ve Robert 1993).

\section{İstatistiksel Analiz}

Elde edilen sonuçların, istatistiksel hesaplamaları SPSS 22 paket programı kullanılarak yapıldı. Gruplar arasındaki istatistiksel farklar normal dağılım göstermeyenlerde Mann-Whitney " $U$ " testi, normal dağılım gösterenlerde ise bağımsız $t$ testi kullanılarak hesaplandı. $\quad \mathrm{P}<0.05$ istatistiksel olarak önemli kabul edildi.

\section{BULGULAR}

Tablo 1'de serum Se ölçümleri için uygulanan ilișkisiz örneklemler için t Testi sonuçları incelendiğinde, Siverek ilçesinde bulunan kuzuların serum Se değerleri istatistiksel olarak anlamlı olacak biçimde Muş ilinde bulunan kuzuların serum Se değerlerine göre daha yüksek bulunmuştur $(\mathrm{P}<0.05)$.

Tablo 1. Serum Se değerlerinin kuzuların yașadığı bölgeye göre farklılık gösterip göstermediğinin incelenmesi amaciyla uygulanan ilişkisiz örneklemler için $t$ testi sonuçları.

Table 1. T test results for unrelated samples applied to examine whether the serum Se values differ according to the region where the lambs live.

\begin{tabular}{llccccc}
\hline & Grup & N$^{*}$ & Ortalama & Sd* & t & $\mathbf{P}^{*}$ \\
\hline \multirow{2}{*}{ Selenyum } & Siverek & 18 & 0.40 & & & \\
& Muş & 18 & 0.36 & & & \\
& & & & & & \\
\end{tabular}

${ }^{*} \mathrm{~N}$ bir gruptaki örnek sayısı, $\mathrm{Sd}$ serbestlik derecesi, $\mathrm{P}$ istatistiksel farklılık

Tablo 2'de yer alan Mann Whitney U Testi sonuçları incelendiğinde, kuzuların serum $\mathrm{Cu}$ değerleri yaşadıkları bölgelere göre istatistiksel olarak anlamlı farklılık göstermemiştir ( $\mathrm{p}>0.05)$.

Tablo 2. Serum Cu değerlerinin kuzuların yaşadığı bölgeye göre farklılık gösterip göstermediğinin incelenmesi amacıyla uygulanan Mann Whitney U Testi sonuçları.

Table 2. Mann Whithney U Test results applied to examine whether the serum $\mathrm{Cu}$ values differ according to the region where the lambs live.

\begin{tabular}{llccccc}
\hline & Grup & $\mathbf{N}^{*}$ & $\begin{array}{c}\text { Sira } \\
\text { Ort. }\end{array}$ & $\begin{array}{c}\text { Sira } \\
\text { toplamı }\end{array}$ & U & P* $^{*}$ \\
\hline \multirow{3}{*}{ Bakır } & Siverek & 18 & 21.22 & 382.00 & & \\
& Muş & 18 & 15.78 & 284.00 & & \\
& & & & & 113.00 & 0.13 \\
\hline
\end{tabular}

*N her bir gruptaki örnek sayısı, p istatistiksel farklılık

Tablo 3'te serum Co ölçümleri için uygulanan Mann Whitney U Testi sonuçları incelendiğinde, Muş ilinde bulunan kuzuların serum Co değerleri istatistiksel olarak anlamlı olacak biçimde Siverek ilinde bulunan kuzuların serum Co değerlerine göre daha yüksek olduğu belirlenmiștir $(\mathrm{P}<0.05)$.

Tablo 3. Serum Co değerlerinin kuzuların yaşadığı bölgeye göre farklılık gösterip göstermediğinin incelenmesi amacıyla uygulanan Mann Whitney U Testi sonuçları.

Table 3. Mann Whithney U Test results applied to examine whether the serum Co values differ according to the region where the lambs live.

\begin{tabular}{lllcccc}
\hline & Grup & N$^{*}$ & $\begin{array}{c}\text { Sira } \\
\text { Ortalama }\end{array}$ & $\begin{array}{c}\text { Sira } \\
\text { toplamı }\end{array}$ & U & P* \\
\hline \multirow{2}{*}{ Kobalt } & Siverek & 18 & 11.64 & 209.50 & & \\
& Muş & 18 & 25.36 & 456.50 & & \\
\hline
\end{tabular}

*N her bir gruptaki örnek sayısı, P istatistiksel farklılık

Tablo 4'te kuzuların serum Se ölçümlerine ait ortalamalara göre Siverek'teki $\left(\bar{X}_{S}=0.3972\right)$ kuzuların Se ölçümüne ait ortalama değeri Muş'taki $\left(\bar{X}_{M}=0.3663\right)$ kuzulara göre 
daha yüksektir. Tablo 4 incelendiğinde benzer biçimde kuzuların minimum ve maximum Se değerlerinin de kuzuların bulundukları bölgeye göre farklılık gösterdiği görülmektedir. Grupların Se ölçümlerinin dağılımlarına ait basıklık ve çarpıklık değerleri ele alındığında, bu değerlerin standart hatalarına oranlarının hem Siverek hem de Muș'ta bulunan kuzular için-1.96 ile +1.96 arasında olduğu, başka bir ifadeyle normal dağılım gösterdiği söylenebilir.

Cu ölçümlerine ait Tablo 4'te yer alan betimsel istatistikler ele alındığında, ortalamaların gruplara göre değişim gösterdiği görülmektedir. Ortalamalara göre Siverek'teki $\left(\bar{X}_{S}=0.6707\right)$ kuzuların $\mathrm{Cu}$ ölçümüne ait ortalama değeri Muş'taki $\left(\bar{X}_{M}=0.6214\right)$ kuzulara göre daha yüksektir. Tablo 4 incelendiğinde benzer biçimde kuzuların, minimum ve maximum $\mathrm{Cu}$ değerlerinin de kuzuların bulundukları bölgeye göre farklılık gösterdiği görülmektedir. Grupların Cu ölçümlerinin dağılımlarına ait basıklık ve çarpıklık değerleri ele alındığında, bu değerlerin standart hatalarına oranlarının Siverek'te bulunan kuzular için -1.96 ile +1.96 arasında olduğu yani normal dağılım gösterdiği ancak Muș ilindeki kuzular için 1.96 ile +1.96 aralığının dışında olduğu yani normal dağılım göstermediği söylenebilir.

Tablo 4'te kuzuların Co ölçümlerine ait betimsel istatistikleri ele alındığında, ortalamaların gruplara göre değişim gösterdiği görülmektedir. Ortalamalara göre Muș'taki $\left(\bar{X}_{M}=0.0197\right)$ kuzuların Co ölçümüne ait ortalama değeri Siverek'teki $\left(\bar{X}_{S}=0.0143\right)$ kuzulara göre daha yüksektir. Tablo 4 incelendiğinde benzer biçimde kuzuların minimum ve maximum Co değerlerinin de kuzuların bulundukları bölgeye göre farklılık gösterdiği görülmektedir. Grupların Co ölçümlerinin dağılımlarına ait basıklık ve çarpıklık değerleri ele alındığında, bu değerlerin standart hatalarına oranlarının Muș'ta bulunan kuzular için -1.96 ile +1.96 arasında olduğu yani normal dağılım gösterdiği ancak Siverek’teki kuzular için -1.96 ile +1.96 aralığının dişında olduğu yani normal dağılım göstermediği söylenebilir.

Tablo 4. Araştırma kapsamında incelenen kuzuların serum Se, $\mathrm{Cu}$ ve Co değerlerinin bölgelere ait betimsel istatistikleri.

Table 4. Descriptive statistics of the serum $\mathrm{Se}, \mathrm{Cu}$ and Co values of the lambs examined within the scope of the study.

\begin{tabular}{|c|c|c|c|c|c|c|c|c|c|c|c|}
\hline \multirow{2}{*}{ 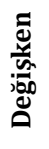 } & \multirow{2}{*}{ Grup } & \multirow{2}{*}{$\mathbf{N}$} & \multicolumn{2}{|c|}{ Ortalama } & \multirow{2}{*}{$\begin{array}{c}\text { Std. Sap. } \\
\text { İst. }\end{array}$} & \multirow{2}{*}{$\begin{array}{c}\text { Min. } \\
\text { İst. }\end{array}$} & \multirow{2}{*}{$\begin{array}{c}\text { Max. } \\
\text { İst. }\end{array}$} & \multicolumn{2}{|c|}{ Çarpıklık } & \multicolumn{2}{|c|}{ Basıklık } \\
\hline & & & İst. & Std. Hata & & & & İst. & $\begin{array}{l}\text { Std. } \\
\text { Hata }\end{array}$ & İst. & Std. Hata \\
\hline & Siverek & 18 & 0.3972 & 0.0095 & 0.0403 & 0.3380 & 0.4710 & 0.1544 & 0.5363 & 1.2541 & 1.0378 \\
\hline \multicolumn{12}{|l|}{ Se } \\
\hline & Muş & 18 & 0.3663 & 0.0086 & 0.0365 & 0.3010 & 0.4230 & 0.0053 & 0.5363 & 0.7170 & 1.0378 \\
\hline & Siverek & 18 & 0.6707 & 0.0611 & 0.2592 & 0.2830 & 1.2650 & 0.8632 & 0.5363 & 0.7563 & 1.0378 \\
\hline \multicolumn{12}{|l|}{$\mathrm{Cu}$} \\
\hline & Muș & 18 & 0.6214 & 0.0751 & 0.3188 & 0.4120 & 1.8490 & 3.7256 & 0.5363 & 14.8685 & 1.0378 \\
\hline & Siverek & 18 & 0.0143 & 0.0025 & 0.0105 & 0.0020 & 0.0490 & 2.0587 & 0.5363 & 7.0017 & 1.0378 \\
\hline \multicolumn{12}{|l|}{ Co } \\
\hline & Muș & 18 & 0.0197 & 0.0005 & 0.0021 & 0.0150 & 0.0230 & 0.7726 & 0.5363 & 0.5804 & 1.0378 \\
\hline
\end{tabular}

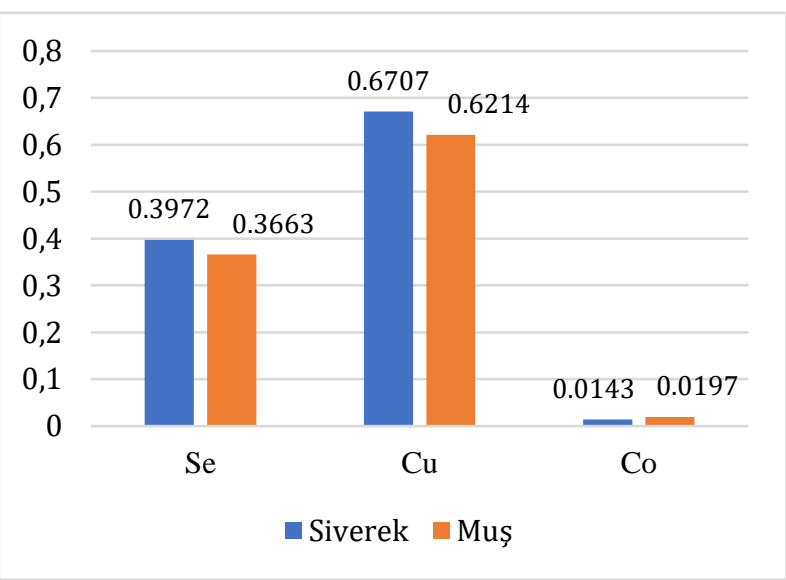

Şekil 1. Araştırma kapsamında incelenen kuzuların serum $\mathrm{Se}, \mathrm{Cu}$ ve $\mathrm{Co}$ miktarlarının Siverek ve Muș bölgelerindeki ortalama değerleri.

Figure 1. Average values of serum $\mathrm{Se}, \mathrm{Cu}$ and $\mathrm{Co}$ amounts in Siverek and Muş regions of lambs examined within the scope of the study.

\section{TARTIŞMA ve SONUÇ}

$\mathrm{Bu}$ çalışma, Siverek ve Muş bölgelerindeki 20-30 günlük Akkaraman ırkı kuzuların serum Se, Cu ve Co değerlerinin , araștırılması ve bu minerallerin yetersizliğinde ortaya çlkabilecek hastalıkların önlenmesi amacıyla yapılmıştır. Örnek seçiminde kuzulara ve gebeliğin son 1 aylık sürecinden numuneler alınıncaya kadar olan süreçte koyunlara herhangi bir mineral madde takviyesi yapılmamıștır.

Siverek'teki kuzuların Muş'taki kuzulardan istatistiksel olarak anlamlı olacak şekilde daha yüksek serum Se miktarına sahip olduğu ancak, her iki bölgede serum Se seviyelerinin referans değerlerden (0.15-0.35 ppm) daha yüksek olduğu görülmektedir. Kuzulara ve annelerine herhangi bir selenyum preparatının uygulanmamış olmasına rağmen serum Se değerinin yüksek bulunmuş olması her iki bölgedeki meraların Se içeriği yüksek olan bitkiler içermesinden kaynaklanıyor olabilir. Qvernes ve arkadaşları (1985) kuzularda serum Se konsantrasyonun 0.15-0.35 ppm arasında olması gerektiğini, 0.1 ppm düzeyinin altına düştüğü durumlarda ise beyaz kas hastalığının şekillendiğini bildirmişlerdir. 
Hayvan beslenmede büyük öneme sahip olan Cu'nun, Türkiye'de yetiștirilen koyunlarındaki miktarı çeșitli araştırmalarla belirlenmiștir (Çamaş ve ark. 1999). Kuzularda serum $\mathrm{Cu}$ seviyesinin 0.80-1.20 ppm değerleri arasında olması gerektiği daha önce yapılan çalışmalarda bildirilmiştir (Faye ve ark. 1990). Kuzularda serum $\mathrm{Cu}$ seviyesinin $0.50 \mathrm{ppm}$ seviyesinin altına düșmesi durumunda enzootik ataksi hastalığının ortaya çıktığı yapılan çalışmalarda rapor edilmiştir (Çamaş ve ark. 1999). Yaptığımız çalışmada, serum $\mathrm{Cu}$ analiz sonuçları değerlendirildiğinde, Siverek ve Muş bölgeleri arasında istatistiksel olarak bir fark tespit edilmemiștir $(\mathrm{P}>0.05)$. Ancak, hem Siverek (0.6707) hem de Muş (0.6214) bölgelerindeki serum örneklerinde $\mathrm{Cu}$ seviyesinin normal değerlerden (0.80-1.20 ppm) daha düşük olduğu belirlenmiştir (Şekil 1). Bu durum subklinik olarak seyreden enzootik ataksi hastalığının olduğunu göstermektedir. Ayrıca Tablo 4 incelendiğinde hem Siverek hem de Muş'tan alınan örneklerde kritik düzeyin (0.50ppm) altında serum $\mathrm{Cu}$ seviyesine sahip kuzular tespit edilmiștir. $\mathrm{Bu}$ durum, topraktaki $\mathrm{Cu}$ miktarının Siverek ve Muș bölgelerinde düșük olmasından kaynaklanıyor olabilir.

Şekil 1'e göre serum Co analiz sonuçları değerlendirildiğinde, hem Siverek (0.0143) hem de Muş'taki (0.0197) kuzuların serum Co seviyeleri referans değerler (0.017-0.051 ppm) arasında olacak şekilde tespit edilmiştir. Co eksikliğinde ortaya çıkan beyaz karaciğer hastalığında kuzuların serum Co değerlerinin 0.017 ppm'den düșük olduğu yapılan çalıșmalarda rapor edilmiștir (Batmaz 2013). Tablo 3 incelendiği zaman serum Co seviyesinin Siverek'teki kuzularda Muș'taki kuzulara oranla istatistiksel olarak anlamlı olacak şekilde düşük olduğu görülmektedir $(\mathrm{P}<0.05)$. Bu durum volkanik bölgelerde toprağın Co seviyesinin düşük olmasıyla açıklanabilir (Aksoy 2016).

Sonuç olarak, Siverek ve Muş bölgelerinde yetiștirilen kuzularda serum Se seviyeleri normal değerlerden yüksek bulunurken, $\mathrm{Cu}$ seviyesi referans değerlerden düşük olarak tespit edilmiştir. Cu yetersizliğine bağlı olarak ortaya çıkan enzootik ataksi hastalığının önlenebilmesi için rasyonla veya ilaç desteğiyle $\mathrm{Cu}$ takviyesinin yapılması önerilebilir. Serum Co değerleri ise her iki bölgede de referans değerler arasında olacak șekilde belirlenmiștir.

\section{ÇIKAR ÇATIŞMASI}

Yazarlar, çıkar çatışması olmadığını beyan eder.

\section{YAZAR KATKILARI}

Fikir/Kavram: VK, MI

Tasarım: VK, MI

Denetleme/Danıșmanlık: VK, MI

Veri Toplama ve/veya İșleme: VK, MI

Analiz ve/veya Yorum: VK, MI

Kaynak Taraması: VK, MI

Makalenin Yazımı: VK, MI

Eleștirel İnceleme: VK, MI

\section{KAYNAKLAR}

Aaseth J, Alexander J, Bjørklund G et al. (2016). Treatment strategies in Alzheimer's disease: A review with focus on selenium supplementation. Biometals, (29), 827-839.

Ahmad MS, Yasser MM, Sholkamy EN, Ali AM, Mehanni MM (2015) Anticancer activity of biostabilized selenium nanorods synthesized by Streptomyces bikiniensis strain Ess_amA-1. Int. J. Nanomed, (10) 33893401
Aitken ID (2009). Diseases of Sheep. 4th Edition, Blackwell UK.

Aksoy G (2016). İz Element ve Vitamin Teminindeki Bozukluklar. İn: Geviş Getiren Hayvanların İç Hastalıkları (Sı̆̆ır, Koyun Keçi). Gül Y. (Ed), 513-534, 4. Baskı. Medipres Yayıncllık, Malatya.

Al Busadah KA (2003). Trace Elements status in camel, cattle and sheep in saudi arabia. Pak Jour of Bio Sci, 6 (21), 1856-1859.

Ayhan 0, Alcigir G, Dincel AS, Yonguc AD, Akcora A (2012). Histopathological and biochemical findings of congenital copper deficiency: are these similar to those of caprine arthritisencephalitis? J Vet Sci, 13(1), 107-9.

Aytuğ CN, Yalçın BC, Alaçam E, et al. (1990). Koyun-Keçi Hastalıkları ve Yetiştiriciliği. Teknografik Matbası, İstanbul.

Bağdaș B, Yıldız AÖ (2004). Broyler rasyonlarına ilave organik selenyum ve vitamin E'nin performans karkas karakterleri ve bazı dokularda selenyum konsantrasyonuna etkileri. SÜ Zir Fak Derg, 18 (34), 94-100.

Batmaz H (2013). Koyun ve Keçilerin İç Hastalıkları Semptomdan Tanıya, Tanıdan Sağaltıma. 1. Baskı Alemdar Ofset, İstanbul.

Bilal T, Bilal T (2005). Koyun-Keçilerin İç Hastalıkları ve Beslenmesi. İstanbul Üniversitesi Basım ve Yayınevi Müdürlüğü, İstanbul.

Bildik A, Yur FG, Belge F, Değer Y, Dede S (2007). Hamdani koyunlarında bazı kan parametrelerinin araştırılması. Vet Bil Derg, 13(1), 17-21.

Bozena H, Martha K, Sylvie S et al. (2017). A Summary of New Findings on the Biological Effects of Selenium in Selected Animal Species A Critical Review. Int J Mol, Sci, 18, 2209, 1-47.

Caglar D, Jung HH, James FC (2018). Intersection of Iron and Copper Metabolism in the Mammalian Intestine and Liver. Compr Physiol, 8(4), 1433-1461.

Can J (1974). Swayback (enzootic ataxia) in Alberta lambs G A Chalmers. Comp Med, Apr 38(2), 111-7.

Cihalova K, Chudobova D, Michalek P et al. (2015). Staphylococcus aureus and MRSA Growth and Biofilm Formation after Treatment with Antibiotics and SeNPs. Int J Mol Sci, 16, 24656-24672.

Combs GFJ, Gray WP (1998). Chemopreventive agents: Selenium. Pharmacol Ther, 79, 179-192.

Çamaş H, Bildik A, Gülser F (1999). Investigation on some trace elements (Cu, Mo, $\mathrm{Zn}, \mathrm{Co}, \mathrm{Mn}$ ) and sulphate in soil, grass and sheep's blood. Van Vet J, 10, 87-91.

Çimtay İ, ölçücü A (2000). Elazığ yöresinde klinik olarak ağlıklı görünen sığırlarda kan plazması ve kıl bakır değerleri üzerinde araștırmalar. Turk J vet Anim Sci, 24, 267-273.

Dabak M, Karataş F, Gül Y, Kızıl Ö (2002). Besi sığırlarında Selenyum ve E vitamini yetersizliğinin araştırılması. Turk J Anim Sci, 26, 741-746.

Duncan WRH, Morrison ER, Garton GA (1981). Effects of cobalt deficiency in pregnant and post parturient ewes and their lambs. British J Nut, 46, 337-344.

Eren V (2009). Rasyona eklenen organik iz minarelerin gebe koyun ve yen doğan kuzularında bazı verim özelliklerine etkisi işle birikim ve atılma düzeylerinin belirlenmesi. Doktora tezi, ADÜ Sağlık Bilimleri enstitüsü, Aydin.

Erika S, János K, István K, János O, Csaba S (2020). Newly Grown Wool Mineral Content Response to Dietary Supplementation in Sheep. Animals (Basel), 11-10(8), 1390

Erkılıç EE, Erdoğan HM (2016). Beyaz karaciğer hastalığı. Türkiye Klinikleri J Vet Sci Med-Special Topics, 2, 70-72.

Faye B, Kamil M, Labonne M (1990). Teneur en oligo-elements dans les fourrages et le plasma des ruminants domestiques en republique de djibouti. Rev Elev Med Vet Pays Trop, 43, 365-373.

Gazioğlu A, Balıkçı E (2017). Geçiş dönemindeki ineklerde serum bakır çinko, manganez ve kobalt düzeyleri. FÜ Sağ Bil Vet Derg, 31(2), 101 104.

Gretchen MH, Marcia CS (2019). Copper and Zinc Nutritional Issues for Agricultural Animal Production. Biol Trace Elem Res, 188 (1),148-159.

Gustavo RGA, Bartira G, Paulo AL, Isabela MB, Dirce M (2018) Dietary Selenium Intake and Subclinical Hypothyroidism: A CrossSectional Analysis of the ELSA-Brasil Study. Marchioni Nutrients, Jun 10(6), 693.

Kennedy S, McConnell S, Anderson H, et al. (1997). Histopathologic and ultrastructural alterations of white liver disease in sheep experimentally depleted of cobalt. Vet Path, 34, 575-584.

Kurt D, Denli O, Kanay Z, Güzel C, Ceylan K (2001). Diyarbakır Bölgesi Akkaraman Koyunların Kan Serumun $\mathrm{Cu}, \mathrm{Zn}$, Se ve Yünde $\mathrm{Cu}, \mathrm{Zn}$ Düzeylerinin Araştırılması. Turk J Vet Anim Sci, 25, 431-436.

MacPherson A, Moon FE, Voss RC (1977). The influence of cobaltdeficient diets on housed sheep. Vet Rec, 101-231.

Malkin R, Malmstrom SG (1970). The state and [unction of copper in BiolOgical systems. Adv in Enzym, 33, 177-244.

Ming S, Miriam BV, Craig JM (2018). Copper-Fructose Interactions: A Novel Mechanism in the Pathogenesis of NAFLD. Nutr, 10(11), 1815. 
Morton S, Robert DJ (1993). Unicam AAS Methods, Manual Issue 2 (05/93) Universty of Bristol, UK Placer. Estimation of product of lipid peroxidation (malonyl dialdehyde) in biochemical systems. Anal Biochem, 16, 359-364.

Pascual A, Aranda A (2013). Thyroid hormone receptors, cell growth and differentiation. Biochim Biophys, 1830, 3908-3916.

Peng F, Guo X, Li Z et al. (2016). Antimutagenic effects of seleniumenriched polysaccharides from pyracantha fortuneana through suppression of cytochrome P450 1A subfamily in the mouse liver. Molecules, 21, 1731.

Pugh DG, Baird AN (2012). Sheep and Goat Medicine. 2nd Edition, Elsevier, Missouri.

Purchase R (2013). The link between copper and Wilson's disease. Sci Prog, 96, 213-23.

Qvernes G, Maksnes K, Frasolie A, Gunnar N, Johanes F (1985). The effect of different levels of selenium in mineral mixtures and salt licks on selenium status in sheep. Acta Vet Scand, 26, 405-416.

Radostits OM, Gay CC, Hinchcliff KW, Constable PD (2008). Veterinary Medicine. Textbo ok of the Diseases of Cattle, Horses, Sheep, Pigs and Goats. 10th St Louis (Ed), Saunders Elsevier, Edinburgh.

Rayman MP (2000). The importance of selenium to human health. Lancet, $356,233-241$.
Shehata E (2019). Changes in Arsenic and Copper Bioavailability and Oxytetracycline Degradation during the Composting Process. Molecules, 24(23), 4240.

Şimşek A (2016). Mangan ve kobalt yetmezliği. Türkiye Klinikleri J Vet Sci Med-Special Topics, 2, 20-24.

Tiftik AM, Doğanay S (1997). İzmir bölgesi koyunlarında kan serumu bakır $(\mathrm{Cu})$, demir ( $\mathrm{Fe})$, total demir bağlama kapasitesi (tdbk) ve çinko (Zn) düzeylerinin araştırılması. Vet. Bil.derg, 13(1), 147-156.

Ting W, Manling S, Xiaoyun S (2020). Seasonal Dynamics of Copper Deficiency in Wumeng Semi-Fine Wool Sheep. Biol Trace Elem Res, 197(2), 487-494.

Underwood EJ, Suttle NF(1999). The Mineral Nutrition of Livestock, 3rd (ed), 294-482, CABI Publishing, UK.

Vellema P, Moll L, Barkema HW, Schukken YH (1997). Effect of cobalt supplementation on serum vitamin B levels, weight gain and survival rate in lambs grazing cobalt-deficient pastures. Veterinary Quarterly, 19, 1-5.

Yalçınkaya İ, Güngör T, Çınar M, Saçaklı P (2010). Broyler rasyonlarında organik selenyum ve vitamin E kullanımının performans, iç organ ağırlıkları ve kan parametreleri üzerine etkisi. Kafkas üniv. Vet fak Derg, 16(1), 27- 32.

Yeşildere T, Deprem 0 (2009). Scott PR. Sheep Medicine. 1. Baskı, Nobel Matbaacılık, İstanbul. 